\title{
Utilization of Feather Meal as a Protein Source in the Diet of Juvenile Japanese Flounder
}

\author{
Kotaro Kikuchi, Takeshi Furuta, and Haruo Honda \\ Abiko Research Laboratory, Central Research Institute of Electric Power Industry, Abiko, Chiba 270-11, Japan \\ (Received October 12, 1993)
}

\begin{abstract}
Feeding experiments were conducted at $20^{\circ} \mathrm{C}$ with diets containing $0,12,25,37$, and $50 \%$ of feather meal to examine the potential of feather meal as a substitute for fish meal in the diet of Japanese flounder. Juvenile fish, about $3 \mathrm{~g}$ in initial body weight, were fed on each diet to satiation twice a day for 6 days a week for 8 weeks.

The weight gain of fish fed on the diets containing 12 and $25 \%$ of feather meal did not differ from that of fish fed on the control diet containing $80 \%$ of white fish meal, however, fish fed on the 37 and $50 \%$ feather meal diets gained less weight. The feed conversion efficiency and protein efficiency ratio of fish fed on the $12 \%$ feather meal diet were almost the same as in the control group, however, these efficiencies decreased as the proportion of feather meal in the diet increased from 25,37 to $50 \%$. Supplements of crystalline amino acids to the feather meal diet improved its nutritive value slightly. There was little difference in the proximate composition of the whole body together with the hematological and hematochemical parameters among the dietary groups tested.

The present study showed that 12 to $25 \%$ of feather meal is an appropriate substitute for fish meal in the diet of juvenile Japanese flounder.
\end{abstract}

Key words: feather meal, dietary protein source, Japanese flounder, growth, body composition

Most of the formulated diets for fish include a lot of fish meal as a protein source because of its high nutritive value and palatability. In Japan, an alternative protein source for fish meal has been the focus of attention in recent years because of falling catches of sardine which are the main ingredients in the diet, and studies on substitutional protein sources have been started with the yellowtail. ${ }^{1-7)}$ Many papers have been written on substitutional protein sources with various kinds of fish such as rainbow trout, ${ }^{8-12}$ carp, ${ }^{13-16)}$ tilapia, ${ }^{17,18)}$ and catfish. ${ }^{19,20)}$ However, information on flatfish is scarce. ${ }^{21,22)}$

The Japanese flounder Paralichthys olivaceus is one of the most important aquaculture species in Japan, and production of the cultured fish ranked fourth among marine cultured finfish in 1991. This species is a highly carnivorous fish which needs a lot of protein (fish meal) for growth. ${ }^{23}$ In the previous paper, ${ }^{24)}$ it was shown that purified soybean meal could replace a large part of the dietary fish meal in the diet of the flounder, however, the use of feather meal as a single source of protein in the diet resulted in very poor growth.

In this study, the availability of feather meal as a partial substitute for fish meal was evaluated using juvenile Japanese flounder by feeding diets containing 0 to $50 \%$ of feather meal.

\section{Materials and Methods}

\section{Experimental Diets}

The ingredients and proximate compositions of the experimental diets are shown in Table 1. Diet 1 was a control diet with $80 \%$ of white fish meal as a protein source. Diets 2 to 5 contained $12,25,37$, and $50 \%$ of feather meal by replacing the fish meal (ratio of white fish meal protein to feather meal protein, $4: 1,3: 2,2: 3$, and $1: 4$, respectively), and were designed to be isonitrogenous to examine the effect of the level of dietary feather meal on the growth of the flounder. In diets 2 to 5 , appropriate quantities of essential amino acids considered to be lacking in feather meal (tryptophan, methionine, lysine, and histidine), were added to each diet based on the difference of amino acid composition between white fish meal and feather meal. The ingredients of diet 6 were almost the same as diet 4 , but did not contain the supplemental amino acids. Diets 4 and 6 were designed to examine the availability of crystalline amino acids in the diet. The feather meal was manufactured by Gunma-ken Kasei Sangyo, Maebashi, Gunma Prefecture. Raw feathers were batch hydrolyzed at $4 \mathrm{~kg} / \mathrm{cm}^{2}$ and 125 to $130^{\circ} \mathrm{C}$ for $60 \mathrm{~min}$. The feathers were then dried in an air dryer at about $200^{\circ} \mathrm{C}$. The feather meal used in this study contained $8 \%$ moisture, $84 \%$ crude protein, $5 \%$ crude lipids, and $2 \%$ crude ash. Mineral and vitamin mixtures were added equally to each diet. The addition of pollack liver oil was changed according to the lipid content of the protein source. All feedstuffs were mixed in a mixer after grinding, and were formed into spheres $2 \mathrm{~mm}$ and $4 \mathrm{~mm}$ in diameter using a twin extruder with the addition of tap water and pollack liver oil. The formulated diets were dried in an air dryer at $20^{\circ} \mathrm{C}$ and stored at $-35^{\circ} \mathrm{C}$. These diets were not designed to be rigidly iso-calorific.

As shown in Table 1, the crude protein contents of the diets were similar, however, the crude lipid contents in diets 4,5 , and 6 were lower. The amino acid composition of the experimental diets are shown in Table 2 , there was no marked difference in the essential amino acid composition except for the lysine content in diets 2 to 5 . The lysine content decreased as the level of feather meal increased, although crystalline lysine- $\mathrm{HCl}$ was supplemented. Meanwhile, the cystine, proline, and serine contents increased, and glutamic acid and aspartic acid decreased as the level of feather meal in the diet increased.

\section{Experimental Procedure}

In January 1993, juvenile flounder of about $1 \mathrm{~g}$ in body weight were transported from a commercial hatchery (Anagawa Shokusan) in Mie Prefecture to our laboratory in Chiba Prefecture. The fish were reared in a $2000 /$ volume seawater aquarium with a commercial diet used for Japanese flounder (Higashimaru Foods Inc.) at $20^{\circ} \mathrm{C}$ until the start of the feeding experiment. The feeding experiment was conducted from February to March using a closed recirculating aquarium of $2000 /$ seawater. The aquarium was placed in the experimental room under natural lighting and the water temperature was kept at $20 \pm 1^{\circ} \mathrm{C}$. At the start of the experiment, the fish were transferred into floating net cages $(30 \times 45 \times 30 \mathrm{~cm}-\mathrm{W} \times \mathrm{L} \times$ H), 25 fish per cage. The fish were fed to satiation twice a day for 6 days a week on each experimental diet of $2 \mathrm{~mm}$ diameter spheres for the initial 
4 weeks, then $4 \mathrm{~mm}$ spheres for the following 4 weeks. The body weight of the fish was measured at the beginning of the experiment, then every 4 weeks after the fish were starved for 36 to $48 \mathrm{~h}$. At the end of the experiment, 12 fish were taken from each dietary group and anesthetized with $0.2 \mathrm{~g} / / \mathrm{MS} 222$ prior to blood drawing. Blood samples were taken

Table 1. Composition of six experimental diets for Japanese flounder

$(\%)$

\begin{tabular}{|c|c|c|c|c|c|c|}
\hline & \multicolumn{6}{|c|}{ Diet } \\
\hline & 1 & 2 & 3 & 4 & 5 & 6 \\
\hline \multicolumn{7}{|l|}{ Ingredient } \\
\hline White fish meal & 80 & 65 & 48 & 32 & 16 & 32 \\
\hline Feather meal*1 & 0 & 12 & 25 & 37 & 50 & 37 \\
\hline Potato starch & 7 & 8.8 & 11.4 & 14.4 & 16 & 17.5 \\
\hline Pollack liver oil ${ }^{* 2}$ & 4 & 4 & 4.5 & 4.5 & 5 & 4.5 \\
\hline Mineral mixture*3 & 5 & 5 & 5 & 5 & 5 & 5 \\
\hline Vitamin mixture*4 & 4 & 4 & 4 & 4 & 4 & 4 \\
\hline Amino acid supplement*5 & 0 & 1.2 & 2.1 & 3.1 & 4 & 0 \\
\hline \multicolumn{7}{|l|}{ Proximate analysis } \\
\hline Moisture & 6.7 & 9.0 & 9.9 & 12.5 & 13,2 & 12.5 \\
\hline Crude protein & 55.5 & 53.2 & 55.6 & 54.3 & 55.2 & 52.6 \\
\hline Carbohydrate & 11.3 & 14.1 & 13.9 & 16.2 & 17.0 & 18.3 \\
\hline Crude lipid & 12.4 & 11.7 & 10.5 & 9.1 & 8.5 & 8.3 \\
\hline Crude ash & 14.1 & 12.0 & 10.1 & 7.9 & 6.1 & 8.3 \\
\hline \multicolumn{7}{|c|}{$\begin{array}{ll}* 1: & \text { Gunma-ken Kasei Sangyo. } \\
* 2: & \text { Riken Vitamin Co., Ltd. (Feed oil } \Omega \text { ). } \\
* 3: & \text { Wolf }(1951) \text {. } \\
* 4: & \text { ZEN-NOH. } \\
* 5: & \text { To } 100 \mathrm{~g} \text { of each diet, } 0.2 \mathrm{~g} \text { of } \mathrm{L}-\text { tryptophan (Trp), } 0.3 \mathrm{~g} \text { of DL-methionine } \\
& \text { (Met), } 0.5 \mathrm{~g} \text { of lysine- } \mathrm{HCl}(\mathrm{Lys}) \text {, and } 0.2 \mathrm{~g} \text { of histidine-HCl (His) were added } \\
& \text { to diet } 2,0.3 \mathrm{~g} \text { of Trp, } 0.5 \mathrm{~g} \text { of Met, } 1.0 \mathrm{~g} \text { of Lys, and } 0.3 \mathrm{~g} \text { of His were added } \\
& \text { to diet } 3,0.4 \mathrm{~g} \text { of Trp, } 0.8 \mathrm{~g} \text { of Met, } 1.5 \mathrm{~g} \text { of Lys, and } 0.4 \mathrm{~g} \text { of His were added } \\
& \text { to diet } 4, \text { and } 0.5 \mathrm{~g} \text { of Trp, } 1.0 \mathrm{~g} \text { of Met, } 2.0 \mathrm{~g} \text { of Lys, and } 0.5 \mathrm{~g} \text { of His were } \\
\text { todded to diet } 5 & \text { a }\end{array}$} \\
\hline
\end{tabular}

from the caudal vessel with $1 \mathrm{~m} l$ heparinized syringes fitted with $23 \mathrm{G}$ needles. Aliquots of the blood were withdrawn, and hematocrit, hemoglobin, and total number of red blood cells were determined within $2 \mathrm{~h}$ after sampling. The rest of the blood was centrifuged for $5 \mathrm{~min}$ at $4,000 \mathrm{rpm}$ to obtain plasma samples, and the samples were stored at $-30^{\circ} \mathrm{C}$ until used. The proximate composition of the whole body was also analyzed.

Analysis

The proximate composition and amino acid composition of the experimental diet and proximate composition of the whole body were

Table 2. Amino acids composition of six experimental diets for Japanese flounder

(mg/g diet)

\begin{tabular}{|c|c|c|c|c|c|c|}
\hline \multirow{2}{*}{ Amino acid } & \multicolumn{6}{|c|}{ Diet } \\
\hline & 1 & 2 & 3 & 4 & 5 & 6 \\
\hline Arginine & 34.1 & 34.4 & 34.1 & 33.3 & 33.7 & 33.6 \\
\hline Lysine & 40.6 & 39.6 & 37.2 & 34.8 & 32.8 & 24.6 \\
\hline Histidine & 11.5 & 11.8 & 11.6 & 10.9 & 10.5 & 8.4 \\
\hline Phenylalanine & 22.2 & 23.1 & 23.9 & 24.3 & 25.5 & 24.4 \\
\hline Tyrosine & 18.8 & 18.2 & 18.4 & 20.1 & 18.1 & 16.0 \\
\hline Leucine & 41.6 & 42.7 & 43.3 & 43.4 & 45.0 & 43.7 \\
\hline Isoleucine & 22.5 & 22.9 & 22.9 & 22.7 & 23.2 & 23.0 \\
\hline Methionine & 15.9 & 16.5 & 15.5 & 15.2 & 14.1 & 8.7 \\
\hline Cystine & 3.6 & 5.7 & 7.8 & 9.4 & 11.1 & 9.5 \\
\hline Valine & 26.9 & 29.3 & 31.9 & 33.8 & 36.8 & 34.4 \\
\hline Alanine & 32.2 & 31.0 & 29.6 & 27.7 & 26.9 & 28.0 \\
\hline Glycine & 37.4 & 38.1 & 38.7 & 38.3 & 39.3 & 38.8 \\
\hline Proline & 20.7 & 26.8 & 30.4 & 36.2 & 40.4 & 37.4 \\
\hline Glutamic acid & 71.9 & 68.3 & 64.3 & 59.6 & 56.7 & 59.9 \\
\hline Serine & 25.9 & 32.0 & 38.3 & 43.5 & 50.5 & 44.4 \\
\hline Threonine & 24.4 & 24.5 & 24.3 & 23.8 & 24.0 & 23.8 \\
\hline Aspartic acid & 51.5 & 48.8 & 45.5 & 41.8 & 39.3 & 41.7 \\
\hline Tryptophan & 6.2 & 7.3 & 7.5 & 7.5 & 8.0 & 4.4 \\
\hline
\end{tabular}

Table 3. Growth data on Japanese flounder fed on the experimental diets for eight weeks

\begin{tabular}{|c|c|c|c|c|c|c|c|c|}
\hline \multirow{2}{*}{ Rearing period } & \multirow{2}{*}{ Diet } & \multicolumn{2}{|c|}{ Av. body wt. $\pm \mathrm{SD}(\mathrm{g})$} & \multirow{2}{*}{$\begin{array}{l}\text { Weight gain } \\
(\%)\end{array}$} & \multirow{2}{*}{$\mathrm{FCE}^{* 1}$} & \multirow{2}{*}{$\mathrm{PER}^{* 2}$} & \multirow{2}{*}{$\mathrm{DFC}^{* 3}$} & \multirow{2}{*}{$\begin{array}{c}\text { Survival } \\
(\%)\end{array}$} \\
\hline & & Initial & Final & & & & & \\
\hline \multirow[t]{6}{*}{ Initial 4 weeks } & 1 & $3.1 \pm 0.4$ & $11.5 \pm 2.3^{\mathrm{a} * 4}$ & 272 & 179 & 3.2 & 2.8 & 100 \\
\hline & 2 & $2.7 \pm 0.4$ & $10.3 \pm 2.3^{\mathrm{a}}$ & 278 & 177 & 3.3 & 2.9 & 100 \\
\hline & 3 & $2.9 \pm 0.4$ & $10.2 \pm 2.5^{\mathrm{a}}$ & 245 & 155 & 2.8 & 3.1 & 100 \\
\hline & 4 & $2.8 \pm 0.3$ & $8.2 \pm 1.4^{\mathrm{b}}$ & 191 & 130 & 2.4 & 3.3 & 100 \\
\hline & 5 & $2.9 \pm 0.4$ & $6.9 \pm 1.5^{\mathrm{c}}$ & 139 & 101 & 1.8 & 3.5 & 100 \\
\hline & 6 & $2.9 \pm 0.4$ & $8.0 \pm 1.7^{b}$ & 176 & 112 & 2.1 & 3.6 & 100 \\
\hline \multirow[t]{6}{*}{ Following 4 weeks } & 1 & $11.5 \pm 2.3$ & $25.8 \pm 8.1^{\mathrm{d}}$ & 123 & 153 & 2.8 & 2.2 & 100 \\
\hline & 2 & $10.3 \pm 2.3$ & $25.5 \pm 7.0^{\mathrm{d}}$ & 147 & 152 & 2.8 & 2.4 & 100 \\
\hline & 3 & $10.2 \pm 2.5$ & $24.9 \pm 7.1^{\mathrm{d}}$ & 146 & 133 & 2.4 & 2.8 & 100 \\
\hline & 4 & $8.2 \pm 1.4$ & $18.8 \pm 5.0^{\circ}$ & 128 & 108 & 2.0 & 3.2 & 100 \\
\hline & 5 & $6.9 \pm 1.5$ & $13.5 \pm 3.3^{f}$ & 96 & 85 & 1.5 & 3.3 & 100 \\
\hline & 6 & $8.0 \pm 1.7$ & $16.1 \pm 4.1^{\mathrm{c}}$ & 101 & 94 & 1.8 & 3.1 & 100 \\
\hline \multirow{6}{*}{$\begin{array}{l}\text { All the period } \\
\text { ( } 8 \text { weeks) }\end{array}$} & 1 & $3.1 \pm 0.4$ & $25.8 \pm 8.1$ & 731 & 162 & 2.9 & 2.1 & 100 \\
\hline & 2 & $2.7 \pm 0.4$ & $25.5 \pm 7.0$ & 833 & 159 & 3.0 & 2.2 & 100 \\
\hline & 3 & $2.9 \pm 0.4$ & $24.9 \pm 7.1$ & 748 & 139 & 2.5 & 2.5 & 100 \\
\hline & 4 & $2.8 \pm 0.3$ & $18.8 \pm 5.0$ & 564 & 114 & 2.1 & 2.8 & 100 \\
\hline & 5 & $2.9 \pm 0.4$ & $13.5 \pm 3.3$ & 367 & 90 & 1.6 & 3.1 & 100 \\
\hline & 6 & $2.9 \pm 0.4$ & $16.1 \pm 4.1$ & 455 & 100 & 1.9 & 3.0 & 100 \\
\hline
\end{tabular}

*1: Feed conversion efficiency ( $\%$, weight gain/feed intake)

*2: Protein efficiency ratio (weight gain/dietary protein intake).

*3: Daily feed consumption (\%).

*4: Values in the same column having the same superscript are not significantly different $(p>0.05)$. 
measured by the methods described previously. ${ }^{23)}$

Hematocrit wass determined with hematocrit capillary tubes, sealed at one end and centrifuged for $5 \mathrm{~min}$ at $12,000 \mathrm{rpm}$. The hemoglobin content was measured by the cyanmethemoglobin method using Hemoglobin-test Wako (Wako Pure Chemical Industries, Ltd.). The total number of red blood cells was determined microscopically using a Thoma hemocytometer after diluting the blood. The hematochemical constituents were analyzed using commercial clinical investigation kits (Wako Pure Chemical Industries, Ltd.) as follows: the biuret method for total plasma protein, the glucose oxidase method for glucose, the GPO $\rho$-chlorophenol method for triglyceride, the MXB method for calcium, and the $\rho$-methylaminophenol method for phosphate.

Differences in body weight, proximate composition of the whole body and hematological and hematochemical parameters between treatments were tested for significance using the Mann-Whitney test.

\section{Results and Discussion}

\section{Growth}

The results of the feeding experiment are shown in Table 3. In all dietary groups tested, fish fed actively through the experimental period and grew well. The weight gain in the initial 4 weeks of rearing was the highest in fish fed on the control diet and the $12 \%$ feather meal (diet 2) diet, and decreased as the level of the dietary feather meal increased (diets 3 to 5). In the following 4 weeks, the weight gain was higher on the 12 and $25 \%$ feather meal diets (diets 2 and 3 ) than the others. The final body weights of fish fed on diets 1 to 3 were almost the same and were significantly higher than those fed on diets 4 to $6(p<0.05)$. A similar trend was observed in the body weight at the end of the initial 4 weeks. The feed conversion efficiency (FCE) and protein efficiency ratio (PER) were the highest in fish fed on the control diet and the $12 \%$ feather meal diet, and tended to decrease proportionally as the feather meal content in the diet increased. The fish fed on the diet supplemented with crystalline amino acids (diet 4) showed slightly better growth than those without supplementation (diet 6).

Utilization of feather meal in the diet of fish was analyzed using rainbow trout Oncorhynchus mykiss. ${ }^{* 1,2}$ It was reported that fish fed on diets containing feather meal and blood meal as substitutional protein sources for fish meal showed far lower growth rates and lower feed conversion efficiencies than fish fed on white fish meal or a commercial diet. It was also shown that the addition of crystalline essential amino acids such as L-tryptophan, L-methionine, and L-lysine-HCl to feather meal resulted in better growth, as shown in this study. On the other hand, in chinook salmon Oncorhynchus tshawytscha, ${ }^{25)}$ the specific growth rate and gross feed efficiencies of fish fed on diets containing 5 and $15 \%$ feather meal instead of fish meal did not differ from those of the fish fed on the control $(0 \%$ feather meal) diet.

\section{Body Composition}

The whole body compositions of the experimental fish are shown in Table 4. There was not marked difference in the moisture, crude protein, and crude ash contents among the dietary groups. However, the lipid level seemed to decrease as the dietary feather meal increased. The moisture, crude protein, and crude lipid contents in diet 5 were significantly different from those in the control diet $(p<0.1)$.

\section{Hematological and Hematochemical Characteristics}

The hematological characteristics and plasma constituents are shown in Table 5. The results are different to previous studies using soybean meal with yellowtail ${ }^{1,2,7)}$ : hemoglobin and red blood cell contents changed, and tended to decrease as the dietary feather meal increased. There was no significant difference in the red blood cell count, but the hemoglobin levels on the feather meal diets (diets 2 to 5 ) were significantly lower than on the control diet $(p<0.1)$. The hematocrit value in diet 1 was not different from those in diets 2 to 5 , and was significantly higher than in diet 6 $(p<0.1)$. In the plasma, protein and phosphate levels seemed to decrease as the dietary feather meal increased.

Table 4. Proximate composition of the whole body of Japanese flounder fed on the experimental dicts for eight weeks

\begin{tabular}{ccccc}
\hline \hline Diet & Moisture & Crude protein & Crude lipid & Crude ash \\
\hline 1 & $74.6 \pm 1.6^{\mathrm{ae} *}$ & $17.3 \pm 0.5^{\mathrm{ab}}$ & $4.4 \pm 0.3^{\mathrm{a}}$ & $3.6 \pm 0.1^{\mathrm{ac}}$ \\
2 & $74.4 \pm 0.2^{\mathrm{a}}$ & $17.5 \pm 0.3^{\mathrm{a}}$ & $3.8 \pm 0.7^{\mathrm{ad}}$ & $3.4 \pm 0.1^{\mathrm{b}}$ \\
3 & $74.1 \pm 1.0^{\mathrm{af}}$ & $17.2 \pm 0.3^{\mathrm{ab}}$ & $4.0 \pm 0.3^{\mathrm{a}}$ & $3.7 \pm 0.1^{\mathrm{c}}$ \\
4 & $75.8 \pm 0.4^{\mathrm{ce}}$ & $16.7 \pm 0.4^{\mathrm{bc}}$ & $3.3 \pm 0.6^{\mathrm{ac}}$ & $3.6 \pm 0.2^{\mathrm{ac}}$ \\
5 & $76.6 \pm 0.3^{\mathrm{b}}$ & $16.7 \pm 0.2^{\mathrm{c}}$ & $2.2 \pm 0.3^{\mathrm{b}}$ & $3.7 \pm 0.1^{\mathrm{c}}$ \\
6 & $75.8 \pm 0.6^{\mathrm{cef}}$ & $16.6 \pm 0.8^{\mathrm{ac}}$ & $3.3 \pm 0.3^{\mathrm{cd}}$ & $3.9 \pm 0.1^{\mathrm{d}}$ \\
\hline
\end{tabular}

* Data represent means and standard deviations for 3 fish. Values in the same column having the same superscript are not significantly different $(p>0.1)$.

Table 5. Hematological characteristics and contents of some plasma constituents of Japanese flounder fed on the experimental diets for eight weeks

\begin{tabular}{|c|c|c|c|c|c|c|c|c|}
\hline Diet & $\begin{array}{l}\text { Hemoglobin } \\
(\mathrm{g} / 100 \mathrm{~m} l)\end{array}$ & $\begin{array}{c}\text { Hematocrit } \\
(\%)\end{array}$ & $\begin{array}{l}\text { Red blood cell } \\
\quad\left(\times 10^{9} / \mathrm{m} l\right)\end{array}$ & $\begin{array}{c}\text { Protein } \\
(\mathrm{g} / 100 \mathrm{ml})\end{array}$ & $\begin{array}{l}\text { Triglyceride } \\
(\mathrm{mg} / 100 \mathrm{~m} /)\end{array}$ & $\begin{array}{c}\text { Glucose } \\
(\mathrm{mg} / 100 \mathrm{~m} /)\end{array}$ & $\begin{array}{l}\text { Phosphate } \\
(\mathrm{mg} / 100 \mathrm{ml})\end{array}$ & $\begin{array}{c}\text { Calcium } \\
(\mathrm{mg} / 100 \mathrm{~m} l)\end{array}$ \\
\hline 1 & $5.3 \pm 0.4^{a *}$ & $26.1 \pm 6.1^{\mathrm{a}}$ & $3.0 \pm 0.6$ & $3.9 \pm 0.2^{\mathrm{a}}$ & $160 \pm 62$ & $61.2 \pm 10.0^{\mathrm{a}}$ & $8.2 \pm 0.3^{\mathrm{a}}$ & $9.0 \pm 1.7^{\mathrm{ab}}$ \\
\hline 2 & $4.7 \pm 0.2^{b}$ & $24.9 \pm 5.9^{\mathrm{abc}}$ & $2.9 \pm 0.5$ & $3.7 \pm 0.1^{\text {tb }}$ & $188 \pm 85$ & $34.8 \pm 11.4^{b}$ & $7.0 \pm 0.7^{b c}$ & $10.1 \pm 1.1^{\mathrm{a}}$ \\
\hline 3 & $4.4 \pm 0.5^{b c}$ & $18.9 \pm 1.3^{\mathrm{ab}}$ & $2.2 \pm 0.3$ & $3.6 \pm 0.0^{b}$ & $188 \pm 32$ & $62.6 \pm 30.1^{\mathrm{abc}}$ & $7.7 \pm 0.7^{\mathrm{ac}}$ & $6.6 \pm 1.9^{\mathrm{b}}$ \\
\hline 4 & $4.0 \pm 0.4^{c}$ & $17.0 \pm 2.4^{\mathrm{abc}}$ & $2.2 \pm 0.2$ & $3.4 \pm 0.3^{\mathrm{b}}$ & $271 \pm 72$ & $42.6 \pm 9.4^{b}$ & $6.7 \pm 1.4^{\mathrm{abc}}$ & $8.3 \pm 1.3^{\mathrm{ab}}$ \\
\hline 5 & $3.6 \pm 0.4^{\mathfrak{c}}$ & $19.6 \pm 6.0^{\mathrm{abc}}$ & $1.8 \pm 0.6$ & $3.3 \pm 0.6^{\mathrm{ab}}$ & $171 \pm 89$ & $60.8 \pm 26.4^{\mathrm{abc}}$ & $6.0 \pm 1.3^{b c}$ & $8.6 \pm 1.3^{\mathrm{ab}}$ \\
\hline 6 & $4.2 \pm 0.3^{c}$ & $15.2 \pm 1.3^{\mathrm{c}}$ & $2.3 \pm 0.3$ & $3.6 \pm 0.3^{\mathrm{ab}}$ & $269 \pm 82$ & $82.9 \pm 7.6^{\mathrm{c}}$ & $6.4 \pm 0.7^{\mathrm{b}}$ & $7.5 \pm 0.8^{b}$ \\
\hline
\end{tabular}

\footnotetext{
*. See the footnote of Table 4
}

*1 The Tokyo Metropolitan Fisheries Experiment Station: Publication of the Tokyo Metropolitan Fisheries Experiment Station No. 281, 1978, $38 \mathrm{pp}$. $44 \mathrm{pp}$. 
Triglyceride, glucose, and calcium contents changed, but these fluctuations did not depend on the dietary feather meal level.

The results of the present study demonstrate that the inclusion of 12 to $25 \%$ feather meal ( 20 to $40 \%$ substitution for fish meal protein) as a substitute for fish meal in the diet of juvenile Japanese flounder is appropriate. This inclusion level is lower than those of soybean meal with yellowtail Seriola quinqueradiate, ${ }^{1,2,4,5,7)}$ and with rainbow trout Oncorhynchus mykiss. ${ }^{11}$ From the result of the previous study, ${ }^{24)}$ in Japanese flounder, the digestibility of feather meal protein was much lower than that of white fish meal or purified soybean meal. This low digestibility is probably why feather meal is generally not used in the diet. The low digestibility of feather meal protein is also reported with chinook salmon. ${ }^{26)}$

In soybean meal, it has been shown that the treatment method such as heating, acid-washing, or alcohol washing has a serious effect on its nutritional value. ${ }^{1,2,10,15)}$ Therefore, it is possible that improving the method of treating feather meal may allow more feather meal to be included in the diet of the flounder than shown in this study.

Acknowledgements The authors wish to thank Professor M. Takeuchi, Faculty of Agriculture, Tohoku University, for his valuable advice and critical reading of the manuscript. Thanks are also due to Dr. M. Kiyono, Biology Department, CRIEPI for supporting this study.

\section{References}

1) S. Shimeno, H. Hosokawa, H. Morie, M. Takeda, and M. Ukawa: Inclusion of defatted soybean meal in the diet of young yellowtail. Suisanzoshoku, 40, 51-56 (1992).

2) S. Shimeno, H. Hosokawa, M. Kumon, T. Masumoto, and M. Ukawa: Inclusion of defatted soybean meal in the diet of fingerling yellowtail. Nippon Suisan Gakkaishi, 58, 1319-1325 (1992).

3) S. Shimeno, H Hosokawa, R. Yamane, T. Masumoto, and S. Ueno: Changes in nutritive value of defatted soybean meal with duration of heating time for young yellowtail. Nippon Suisan Gakkaishi, 58, 1351..1359 (1992).

4) T. Watanabe, V. Viyakarn, H. Kimura, K. Ogawa, N. Okamoto, and N. Iso: Utilization of soybean meal as a protein source in a newly developed soft-dry pellet for yellowtail. Nippon Suisan Gakkaishi, 58, 176-173 (1992).

5) V. Viyakarn, T. Watanabe, H. Aoki, H. Tsuda, H. Sakamoto, N. Okamoto, N. Iso, S. Satoh, and T. Takeuchi; Use of soybean meal as a substitute for fish meal in a newly developed soft-dry pellet for yellowtail. Nippon Suisan Gakkaishi, 58, 1991-2000 (1992).

6) S. Shimeno, T. Masumoto, T. Hujita, T. Mima, and S. Ueno: Alternative protein sources for fish meal in diets of young yellowtail. Nippon Suisan Gakkaishi, 59, 137-143 (1993).

7) S. Shimeno, M. Kumon, H. Ando, and M. Ukawa: The growth performance and body composition of young yellowtail fed with diets containing defatted soybean meal for a long period. Nippon Suisan Gakkaishi, 59, 821-825 (1993).

8) A. G. J. Tacon, J. V. Haaster, P. B. Featherstone, K. Kerr, and A. J. Jackson: Studies on the utilization of full-fat soybean and solvent extracted soybean meal in a complete diet for rainbow trout. Nippon
Suisan Gakkaishi, 49, 1437-1443 (1983).

9) K. Dabrowski, P. Poczyczynski, G. Kock, and B. Berger: Effect of partially or totally replacing fish meal protein by soybean meal protein on growth, food utilization and proteolytic enzyme activities in rainbow trout (Salmo gairdneri). New in vivo test for exocrine pancreatic secretion. Aquaculture, 77, 29-49 (1989)

10) T. Murai, H. Ogata, A. Villaneda, and T. Watanabe: Utilization of soy flour by fingerling rainbow trout having different body size. Nippon Suisan Gakkaishi, 55, 1067-1073 (1989).

11) J. Pongmaneerat and T. Watanabe: Utilization of soybean meal as protein source in diets for rainbow trout. Nippon Suisan Gakkaishi, 58, 1983-1990 (1992).

12) J. Pongmaneerat and T. Watanabe: Nutritional evaluation of soybean meal for rainbow trout and carp. Nippon Suisan Gakkaishi, 59, 157-163 (1993).

13) S. Viola, S. Mokady, U. Rappaport, and Y. Arieli: Partial and complete replacement of fishmeal by soybean meal in feeds for intensive culture of carp. Aquaculture, 26, 223-236 (1981/1982).

14) H. Abel, K. Becker, C. Meske, and W. Friedrich: Possibilities of using heat-treated full-fat soybeans in carp feeding. Aquaculture, 42 , 97-108 (1984)

15) T. Murai, H. Ogata, P. Kosutarak, and S. Arai: Effect of amino acid supplementation and methanol treatment on utilization of soy flour by fingerling carp. Aquaculture, 56, 197-206 (1986).

16) T. Murai, W. Daozun, and H. Ogata: Supplementation of methionine to soy flour diets for fingerling carp (Cyprinus carpio). Aquaculture, 77, 373-385 (1989).

17) S. Y. Shiau, J. L. Chuang, and C. L. Sun: Inclusion of soybean meal in tilapia (Oreochromis niloticus $\times O$. aureus) diets at two protein levels. Aquaculture, 65, 251-261 (1987).

18) S. Y. Shiau, S. F. Lin, S. L. Yu, A. L. Lin, and C. C. Kwok: Defatted and full-fat soybean meal as partial replacements for fishmeal in tilapia (Oreochromis niloticus $\times O$. aureus) diets at low protein level. Aquaculture, 86, $401-407$ (1990).

19) A. A. Mohsen and R. T. Lovell: Partial substitution of soybean meal with animal protein sources in diets for channel catfish. Aquaculture, 90, 303-311 (1990).

20) C. D. Webster, J. H. Tidwell, L. S. Goodgame, D. H. Yancey, and L. Mackey: Use of soybean meal and distillers grains with solubles as partial or total replacement of fish meal in diets for channel catfish, Ictalurus punctatus. Aquaculture, 106, 301-309 (1992)

21) C. B. Cowey, J. A. Pope, J. W. Adron, and A. Blair: Studies on the nutrition of marine flatfish. Growth of the plaice Pleuronectes platessa on diets containing proteins derived from plants and other sources. Mar. Biol., 10, 145-153 (1971).

22) C. B. Cowey, J. Adron, A. Blair, and A. M. Shanks: Studies on the nutrition of marine flatfish. Utilization of various dietary proteins by plaice (Pleuronectes platessa). Br. J. Nutr., 31, 297-306 (1974)

23) K. Kikuchi, H. Honda, and M. Kiyono: Effect of dietary protein level on growth and body composition of Japanese flounder, Paralichthys olivaceus. Suisanzoshoku, 40, 335-340 (1992).

24) K. Kikuchi, H. Honda, M. Kiyono, and 1. Miyazono: Total replacement of fish meal with other protein sources in the diet of Japanese flounder. Suisanzoshoku, 41, 345-351 (1993).

25) L. G. Fowler: Feather meal as a dietary protein source during parr-smolt transformation in fall chinook salmon. Aquaculture, 89 301-314 (1990)

26) W. E. Hajen, D. A. Higgs, R. M. Beames, and B. S. Dosanjh: Digestibility of various feedstuffs by post-juvenile chinook salmon (Oncorhynchus tshawytscha) in sea water. Measurement of digestibility. Aquaculture, 112, 333-348 (1993). 